\title{
Advocacy and licensing: Essential tools for professional foresters' associations - Case study of the Ordre des ingénieurs forestiers du Québec ${ }^{1}$
}

\author{
G.W. Crook, ing.f. ${ }^{2}$
}

The Ordre des ingénieurs forestiers du Québec has for 75 years played a key role in building the public's awareness of forests and of the practice of professional forestry, and in safeguarding the public interest in the resource. Two primary drivers are behind the organization's success: a long-standing advocacy policy and licensing. As a professional association that has been given the right to exclusive practice, it is legally bound to place as its highest priority the protection of the public good. This necessitates an inspection, discipline, and continuing education program for its members to ensure their competency. Also, the Order has the mandate of ensuring that foresters are not impeded in their professional practice. Its advocacy and communications mandate is closely linked to its role, specified in its Code of Ethics, to protect the public by speaking out on forestry-related issues. The Order has thus been able to rise above partisan issues and base its position statements and policies on the reservoir of expertise that it collectively represents. The result has been the promotion of professional forestry for the public good, and the Order taking a leadership role as the conscience of forestry in Quebec.

\section{Introduction}

Since its founding in 1921, the Ordre des ingénieurs forestiers du Québec has played a key role in influencing provincial government policy in forestry issues. Its imprint on the practice of forestry and on the protection of the public interest stems directly from the vision it has had of itself as a professional organization since its founding.

A 1500-page Manuel de foresterie (Forestry Handbook ${ }^{3}$ ) released at its 75th anniversary annual general meeting (AGM) represents a tremendous achievement for the Order. One may wonder how a provincial professional foresters' association had the depth and the resources to produce such a document. This article will show that the answer lies in the organization's history - starting with the visionaries who laid the foundations.

Today, the OIFQ's mission is to:

- ensure the quality of services rendered to Quebec society by forest engineers, ${ }^{4}$ individually and collectively;

- increase the expertise of forest engineers;

\footnotetext{
${ }^{1}$ Quebec Order of Forest Engineers, referred to in this article as the Order or the OIFQ. The current name was adopted in 1974.

${ }^{2}$ Canadian Forest Service, Great Lakes Forestry Centre, Sault Ste. Marie, Ontario. Ing.f. (ingénieur forestier) is the Quebec equivalent to R.P.F.

${ }^{3}$ Any translations done by the author appear in sans serif font, but do not necessarily correspond to official translations, if available. Official translations appear in italic.

${ }^{4}$ The term 'forest engineer' in Quebec is equivalent to the term 'forester', not to be confused with the field of 'forest engineering', a specialty taught, for example, at the University of New Brunswick.
}

L'Ordre des ingénieurs forestiers du Québec joue depuis 75 ans un rôle déterminant au niveau de la sensibilisation du public envers les forêts et la pratique de la foresterie professionnelle, tout en protégeant les intérêts du public dans cette ressource. Deux principaux éléments sont à la base du succès de l'organisation : une politique de protection de la ressource établie depuis longtemps et le fait d'être une corporation professionnelle. En tant que corporation professionnelle à champ de compétence exclusive, elle est légalement tenue d'agir en priorité pour la protection des biens publics. Cela implique un programme d'inspection, un code de discipline, ainsi qu'un programme de formation continue pour ses membres afin de maintenir leur compétence. De plus, l'Ordre a le mandat de s'assurer que les forestiers ne connaissent pas d'entrave dans l'exercice de leurs fonctions. Son mandat de défense de ses intérêts et de communication est étroitement lié à sa mission, telle que définie dans son code d'éthique, de défense des intérêts publics en matière de foresterie. L'Ordre a ainsi pu s'élever au-dessus des questions partisanes et appuyer ses prises de position et ses politiques en tenant compte de l'ensemble de l'expertise accumulée par tous ses membres. Il en résulte une promotion de la foresterie au niveau professionnelle pour le bien du public, tout en assumant un rôle de leadership en tant que conscience de la foresterie au Québec.
- see that the management of the province's forest heritage ensures its sustainability, while favouring the growth of the forestry sector;

- ensure that the forest is used as the driver for the socioeconomic development of all regions of Quebec.

\section{History of the OIFQ}

The beginnings of the OIFQ are linked to the founding of postsecondary forestry education in Quebec at Laval University in 1910. By 1916 about 30 individuals had graduated from the faculty. As a first step in their efforts to secure legal status as a profession, this group of foresters established an informal group in that year, the Association of Forestry Engineers of the Province of Quebec. These foresters argued that their university training was as rigorous as that of civil engineers and of the nine other professions that had already received legal recognition. The situation, as reported in Côté (1996), was described by one of the Association's founders, O. Lussier, in words that are as true today, "Circumstances will soon come about where foresters will have to rule upon questions of forest management, and it will be preferable to be legally recognized by a professional charter".

By steady efforts (among other things, defending their mission from derailment attempts by civil engineers, who did not want to see their territory invaded by a competing profession) the Association of Forestry Engineers of the Province of Quebec in 1921 became the tenth profession to be given legal status, but only right to title was conferred. 
Immediately after securing right to title, the members set about working to gain the exclusive right to practice professional forestry and to be placed on an equivalent legal standing with other professions in the province. This was achieved in 1929, and in 1949 the law was revised into the form of licensing seen today.

\section{Legal Foundation}

The OIFQ is one of 43 legally recognized professional corporations now recognized in Quebec. Since 1974, the province's professions have been regulated by a piece of umbrella legislation called the Professional Code. The terms of this code and of the Forest Engineers Act are described in some detail in Krystofiak (1996).

\section{Professional Code}

The main purpose of the Code is to protect the public safety by obliging professional associations to ensure the competency of their members. The Code is predicated on the objective that professionals practice on behalf of the public good; thus the Code states that professional associations are not allowed to exist except "where the acts done by those persons are of such a nature... that for the protection of the public they cannot be done by persons not having the training and qualifications required to be a member of the (professional) corporation." The realization that professionals are the repository of specialized knowledge, to be used on behalf of the greater public good, is the cornerstone of professionalism in Quebec.

\section{Forest Engineers Act (excerpts)}

"The expression 'forest engineer' is used when referring to any person practising the profession of engineer and qualified to give advice upon or supervise, execute, or direct the execution of the following works." The Act provides a detailed list of the acts that are reserved for professional foresters by the power of licensing, or "exclusive exercise", including: "the inventory, classification, and valuation of forest soils and crops, preparation of maps and topographical plans of forests; the management, maintenance, conservation, lumbering, reforestation, and protection of forests; silviculture; forest photogrammetry; logging and transportation of wood; harvesting of forests and other forest resources; preparation of maps, estimates and specifications, and any engineering work related to forest management."

Besides being given the exclusive right to practice specific acts, the title is also protected: other than a member of the Order, "No person may take the title of forest engineer in Quebec, or use any name, title or designation which may cause it to be understood that he is a forest engineer ..."

Based on the preceding list of professional acts, persons working in the following areas have no legal requirement to be registered foresters: federal forestry research organizations, forestry professors at universities and colleges, and employees of forestry associations; nevertheless, many such persons choose to be members of the OIFQ. Unlike Ontario, to be employed as a forester with the Quebec Ministry of Natural Resources a person must be a member of the Order. This includes field foresters, supervisors, and district managers, but not senior management positions.

To be accepted as a member of the OIFQ, one must have a degree in forestry, have 32 weeks of forestry experience, and the ability to communicate in French. For persons with a degree from a Canadian university, the only other requirement is to pass an exam on Quebec forestry legislation. Foreign-trained foresters usually must pass a series of examinations covering a range of forestry subjects.

\section{Code of Ethics}

The OIFQ's first code of ethics was adopted in 1934. In 1967 it was updated and expanded into a Code of Ethics and a Code of Practice. This set of regulations governs the day-today professional life of foresters.

According to the Code of Ethics, and stemming from the right to exclusive practice "the forester must inform the public or the Order when he considers that a forest policy, measure, or disposition may be detrimental to the forest heritage." The Order's policy of protecting the public good via a strong advocacy and communications role is based on this part of the Code of Ethics.

\section{Inspection of the membership}

Because the principal reason for the existence of professional associations is the protection of the public, they must each regulate their members' competency. In the case of the OIFQ, this is carried out by an inspection program managed by a standing committee. It oversees members' practice of forestry, reviews their professional competence, and disciplines them when required. Also, it informs the Administrative Council of any situation that presents difficulties to members in the practice of their profession.

To ensure the competency of its members, the Order recently increased the number of annual inspections from 50 to 250 so that all members can be inspected once every 6 years. In the last year, the Professional Inspection Committee reviewed the inspection procedures used by other professions and clarified the definition of professional competence.

\section{Continuing education}

Because the Professional Code obliges professional associations to ensure the competency of their members, the Order sees continuing education as an essential role. Only if members keep their knowledge and skills current can they fulfil their responsibilities to the public.

Starting in 1975, the OIFQ undertook a continuing education program. Since that time, 50 courses and 36 workshops have been given, with an average of 22 and 104 participants per event, respectively. The courses and workshops, of a one or two day duration, are usually presented via educational institutions such as Laval University, and usually cost about \$100.

In 1987 the Order began publishing continuing education courses in its news bulletin, L'Aubelle. These are prepared by a variety of authors, usually forestry professors or researchers with the federal or provincial governments. To date, 37 courses have been offered in L'Aubelle, with an average of 59 participants writing the exam that is included with each course. Based on the OIFQ's formula, the Society of American Foresters is currently examining this approach.

\section{Management Structure and Operations}

The OIFQ has nine sections, with a permanent secretariat located logically in the section having the most members-Quebec City and area, ${ }^{5}$ where the Ministry of Natural Resources has its

\footnotetext{
${ }^{5}$ The address of the OIFQ is: 2750 , rue Einstein, Sainte-Foy, QC G1P 4R1.
} (Tel.418-650-2411; E-mail: oifq@mediom.qc.ca). 
headquarters. Each section elects one representative to the Administrative Council, except Quebec, which elects five. The Administrative Council is made up of 17 members - 14 elected (including the President) and three (18\%) appointed by the Office of Quebec Professions to represent the public. They are elected for a period of 3 years; to stand for election they must receive supporting signatures from 10 members. Council elects a Board of Directors composed of five persons: four foresters (President, Vice-President, Treasurer, Administrator) and one of the administrators appointed to Council by the Office of Professions.

The nine sections were established in 1964 to provide for better representation of the regions on Council. Sections are active, with a board of directors made up of five to seven members. Section executive organize three to four events each year for the local membership, as well as the annual meeting of the Order when it is held in their section (the host section keeps half of the net profit from the annual meeting usually a sum of $\$ 6,000-8,000$ ). Activities include training events, field trips, and informal gatherings. Up to $\$ 1,000$ is available from Council for each section, if needed, to help deliver their program.

The sections also nominate members to receive annual awards, and write a column on their activities in L'Aubelle. In 1989 , the Order prepared a guide to improve the sections' operating efficiency and to provide them with a similar structure, thus encouraging more participation by members.

\section{Annual Meeting}

The financial year of the OIFQ ends 31 March, and the AGM is held in September. During the past 5 years attendance has averaged $15-20 \%$ of practising members, or about 250 per meeting. The AGM rotates throughout all nine sections, so a given section plays host to it once every nine years.

\section{Permanent Secretariat}

The first permanent secretariat with an Executive Director was established in 1965. The secretariat staff is now made up of a President/Executive Director, Director of Communications, Executive Secretary (positions held by foresters), and two clerical staff.

Also in 1965, the OIFQ and 14 other professions founded the Interprofessional Council of Quebec. This organization now regroups 263000 professionals. Its mission is to find solutions to common problems facing professional associations in the province.

As of 1996, the OIFQ President serves full time in the combined position of President and Executive Director. This modification was initiated to improve the Order's public standing, enhance its ability to serve the membership, and facilitate achievement of its goals as regards its public role. The workload for the President had become too onerous to be adequately carried out by a part-time volunteer.

\section{Volunteers}

Without the participation of volunteer members, the OIFQ could not function. It is estimated that in any given year $8-10 \%$ of the total membership (about 150 persons) serve as volunteers in many roles: Administrative Council, Board of Directors, standing committees, boards of outside committees, section executive, annual meeting organizing committee, preparation of position papers, notices, and other materials, and organizers of events such as the members' annual golf tournament. Volunteers have played a significant role in the Order since its inception, and the long list of published documents that have helped to shape public forestry policy over the decades are a testimony to their work.

It is of note that, even in the early days when fewer than 50 members made up the membership, the Order was able to put forward major position papers for consideration by the government and the general public. Based on the media coverage they received, the Order was well ahead of its time. ${ }^{6}$

\section{Annual Budget}

With a current membership base just shy of 2000, the Order has the necessary funds to undertake the energetic program it has set for itself. Table 1 provides some highlights of principal sources of revenue and expenditures.

\section{Membership and Dues}

In 1921, the approximately 50 founding members paid less than $\$ 10$ in annual dues. The Order has since grown into a mature professional association (Table 2). Figure 1 shows how the membership and annual dues have evolved over the life of the organization. Dues for 1997-1998 are \$335.

\section{Standing Committees}

As reported in the 1996 annual report, the OIFQ had the following standing committees in place. The number of committee members and the number of meetings held during the year are shown in parentheses 0 and square brackets [], respectively.

\begin{tabular}{lr}
\hline Table 1. Principal elements of the OIFQ's 1995-1996 annual budget (000\$) \\
\hline Total revenues & 661 \\
Membership dues & 557 \\
Annual meeting & 67 \\
Continuing education tuition & 19 \\
Ads sold in L'Aubelle & 9 \\
Ads sold in membership directory & 7 \\
& \\
Total expenses & 740 \\
Annual meeting & 46 \\
L'Aubelle news bulletin & 42 \\
Professional inspections & 25 \\
Continuing education & 15 \\
OIFQ stand & 8 \\
Membership directory & 7 \\
Publicity & 6 \\
\hline
\end{tabular}

Table 2. Total membership of the OIFQ and the number of members practising for selected years. Total membership includes retired, unemployed, and other members who are not in the work force

\begin{tabular}{lrlr}
\hline \multicolumn{2}{r}{ Total membership } & \multicolumn{2}{c}{ Number practising } \\
\hline 1996 & 1913 & 1996 & 1608 \\
1991 & 1797 & 1991 & 1537 \\
1981 & 1223 & 1981 & 1091 \\
1971 & 680 & 1971 & 620 \\
1961 & 222 & 1961 & 220 \\
\hline
\end{tabular}

${ }^{6}$ Public opinion polls have for some time revealed that the general public places the least confidence in politicians and the most in scientists and professionals. Thus, even our pollsters are indicating the potential for a strong advocacy role for professional foresters' associations. 


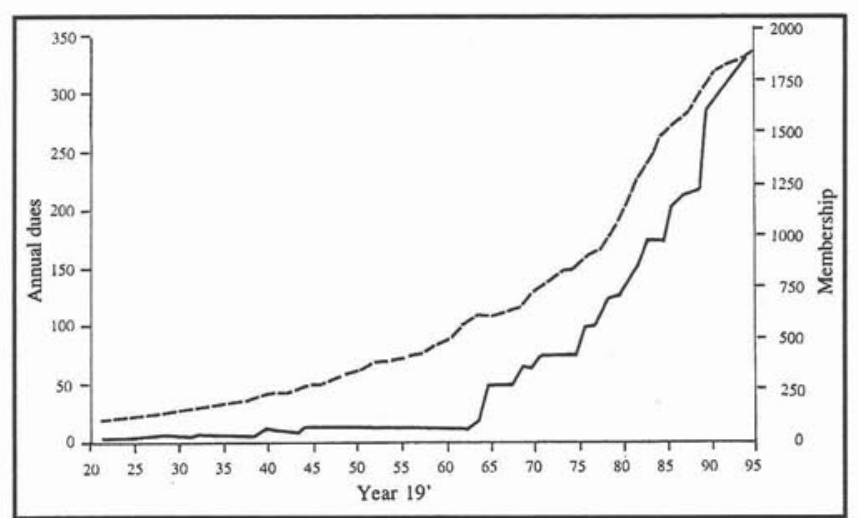

Fig. 1. Evolution of the membership and the annual dues of the OIFQ, 1921-1995.

1. Administrative Council (17)[8]

2. Board of Directors (5)[7]

3. Professional Responsibility Insurance Committee (3)[4]

4. L'Aubelle Advisory Committee (5)[4]

5. Certification of Forest Practices Committee (14)[4]

6. Communications Committee (7)[3]

7. Finance Committee (5)[2]

8. Examiners Committee (5)[3]

9. Private Forestry Committee (10)[2]

10. Continuing Education Committee (8)[5]

11. Training of Forest Engineers Committee (6)[2]

12. Professional Inspection Committee (8)[7]

13. Forestry Handbook Committee (7)[3]

14. 75th Anniversary Committee (6)[4]

The OIFQ has a member sitting on the boards of a number of other organizations:

1. Canadian Forestry Accreditation Board

2. Advisory Committee on Integrated Resource Management

3. Faculty Distinctions and Awards Committee, Faculty of Forestry and Geomatics, Laval University

4. Laval University Program Committee in Forestry and Environmental Management

5. Laval University Program Committee in Forestry Operations

6. Laval University Program Committee in Wood Science

7. Board of Directors, Marcel Lortie Foundation

8. Interprofessional Council of Quebec

9. Macpès Forest Corporation

10. Rural Solidarity

11. House of the Tree, Montreal Botanical Gardens

In most cases the Order is requested to sit on various boards, but in cases where it is not invited and where it judges necessary that professional forestry be represented, it will request representation.

\section{Peer Recognition}

The OIFQ provides two awards to its members to recognize their professionalism and accomplishments, and to help raise the profile of the Order:

- Forester-of-the-year: recognizes an exceptional contribution in the promotion of forestry in Quebec.
- Medal of the Order: recognizes exceptional service rendered to the forestry profession in Quebec during a member's career.

- In 1996 an award was established to recognize non-members for an exceptional contribution or service to forestry, or for developing or promoting the profession (the Henri-GustaveJoly de Lotbinière Award).

\section{Other Awards}

Financial aid is provided to forestry students and forestry activities at Laval University:

- Prix de l'Ordre: \$500 annual prize awarded to a student entering 4th year who has a distinguished academic and extra-curricular record.

- Student activities: donation of $\$ 250$ per year to the yearbook, and financial assistance for an annual event, the student-organized Forest Sciences Week, consisting of free advertising in L'Aubelle worth $\$ 700$, and $\$ 900$ for a kiosk.

\section{Services to Members}

A number of services are offered to members:

Membership directory: more than just a listing of members' names, employer, etc., it serves as a handy desk reference for a range of information: members on Council, Board of Directors, permanent secretariat staff, professional inspector; names and addresses of the regional representatives who serve on Council; names of the Chair and Secretary of each of the standing committees; historical information (ten most recent past presidents and the winners of OIFQ awards); location of the next six annual meetings; and the addresses of Canadian and American professional foresters' associations; the addresses of over 20 forestry-sector organizations (e.g., CPPA, FERIC). The Order sells space in the directory to forestry consultants to offset publishing costs. In 1996, 48 firms placed an ad in the directory, which covered all publishing costs (see budget items above).

Job offers: job descriptions for positions available within and outside Quebec are sent to members in regular mailings (about 30 per year).

Professional benefits: the OIFQ has joined many other professional associations in the province to gain a range of benefits for its members at reduced group rates. Goods and services are offered through a company called La Professionelle at no cost to members or the Order, including: car, house, and personal insurance; automobile purchasing and rental; optical, travel agency, fitness club, papers and magazines, ski resorts, hotels, preferential bank loans, gas, service station work, Internet service provider, and others. The availability of these 'non-essential' services to members may help to entice those who do not legally require membership to nevertheless takeout membership.

\section{Communications and Advocacy}

Since its inception the Order has given its members, the general public, and the government a professional perspective on forestry issues. To do this it has used a variety of communications tools, including position papers and notices that are released to the public, working documents that are prepared for use by members, and the news bulletin, L'Aubelle. 


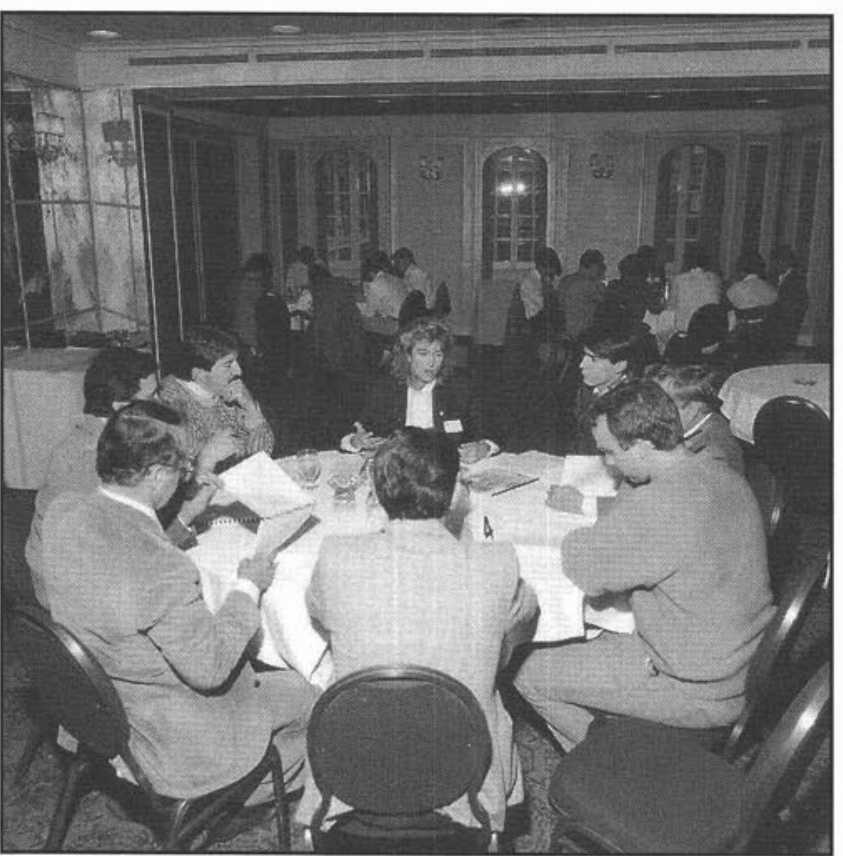

Fig. 2. Members meet to discuss and plan the future orientation of the Order.

In the mid 1980s, OIFQ members were questioning the organization's operations and how it could develop a higher public profile. To address issues that had been simmering among the membership, the 1987 AGM was devoted to deliberations on the future orientation of the Order. Here, "260 foresters became aware of the raison d'être of their professional body and expressed themselves on its future" (Côté 1996) (Fig. 2).

To adequately prepare members for this decision-making process, the membership was kept thoroughly informed: members were polled through the mail and, based on the results, several documents were prepared to bring them up to date on the issues and help with their pre-meeting deliberations. In a mail referendum held a few months after the AGM, members voted on 13 key proposals that had been put forward. Strictly following the results, Council prepared an action plan to:

- rework the Code of Ethics,

- revise the Forest Engineers Law and the Code of Practice,

- redefine the field of exclusive practice,

- give more attention to training,

- establish a communication plan and hire a Director of Communications to put it into effect (necessitating a 30\% increase in dues that had previously been approved by the membership at the 1987 AGM).

Most of the items covered in the action plan were achieved between 1988 and 1993.

Communications Plan. Since hiring a full-time Director of Communications in 1988, the Order regularly produces a communications plan to direct the actions to be taken in this area. Besides position papers and L'Aubelle, the Order prepares a range of publications for its members (e.g., working document on clear-cutting, 1996 salary survey), and forestry partners, and directs some efforts at educating the general public (e.g., pamphlets on specific issues, kiosks at expositions, advertisements).

As fate would have it, a short time after the Order decided to formally embrace advocacy and a communications program, there appeared a 'test case'.

A group of developers received support in the late 1980s from the Bourassa government to build condominiums on Crown lands at the teaching and research forest used by the Duchesnay Forest Ranger School and Ministry of Natural Resources researchers. The OIFQ mounted a vigorous challenge to this plan, and held press conferences to give evidence of the detrimental impact such a development would have on important on-going environmental research and the use of the forest for educational purposes. After a number of months the government backed down and the Duchesnay forest later received official protection in the Forest Law of Quebec.

The Order made it clear throughout the Duchesnay public relations campaign that it was bound by its Code of Ethics to speak out to protect the forest. The "Duchesnay affair" demonstrated to the public the Order's independence from government policy and did much to raise the professional profile of foresters (and their self-esteem).

Forestry Handbook. The largest undertaking by the OIFQ to date has been the publication of a Manuel de foresterie. This project began in 1993 and culminated with the release of the manual at the 75th AGM in September 1996. The 32 chapters of the 1500 page text, written by 165 authors, address the entire field of forestry. A hundred financial partners backed the project, but the most important were the Canadian Forest Service and the Quebec Ministry of Natural Resources. Each member paid an extra \$25 on their 1997 dues to help defray publication costs.

The manual will make its way into forestry circles throughout the French speaking world; it will therefore be a major marketing tool for the OIFQ and a source of pride for the foresters of Quebec. It will be used as a reference by forestry students and practitioners alike.

Tradition of Advocacy. Though the change in direction brought about by the 1987 AGM was pivotal in the evolution of the Order because of the breadth of change it initiated, the OIFQ had nevertheless made advocacy a priority from its beginnings. In 1922, the year following the organization's founding, the first position paper was published (a recommendation to immediately create permanent forest reserves in the areas most unsuited for agriculture), and two other major papers were released before 1929 , the year licensing was accorded.

In 1938, the President stated the Order's position on advocacy: "If we do not express our opinion concerning the administration of our natural resources, especially those that have been entrusted to us as experts, the public will hold us responsible for any bad legislation passed because public opinion will not have been sufficiently awakened." This philosophical stamp, combined with the members' desire to have a professional association that took its responsibilities toward the public seriously, has remained at the heart of the Order's policy on advocacy and communications.

The position papers and notices published by the OIFQ on forestry issues are too numerous to list here. However, some of them have played an instrumental role in the development of provincial forestry 
legislation and policy. A partial listing of the Order's position papers reveals its energy and far-sighted vision:

1923: recommends an inventory of the province's pests, and that silviculture treatments be done to ensure regeneration.

1924: calls for the creation of a Forest Research Bureau. (The Order continued to call for such a bureau for decades, but the government would not take action. Finally, in 1969, the Forest Research and Development Council was created.)

1938: publishes one of the most far-reaching policy documents in its history, the "Program of Action and Forest Policy for Quebec." Recommendations are made for the formation of the Quebec Forestry Association (established the following year), other items proposed are: a provincial forest inventory program; forest management and protection activities; silvicultural practices to increase yields; a forestry research program; organization of forest resources for recreation; establishment of demonstration forests; reorganisation of the provincial forest service; rewriting the laws and regulations of the Department of Lands and Forests.

1940: because private woodlots were then being liquidated to produce pulpwood for industry, recommendations are made to government to rectify the situation. The result is a series of measures, including the creation of a Forestry Information Bureau and a forestry education and extension program for woodlot owners.

Since 1939,48 position papers and 44 notices have been published, including 15 in the 1990 s alone. These have been prepared on issues such as: forestry conservation, administration of forests, multiple-use forest management, reforestation, forestry research, forestry education, protection of agricultural lands (in collaboration with the Quebec Order of Agrologists ${ }^{8}$ ), spruce budworm spraying, herbicides, private forestry, forest policy in Quebec, pesticides, forestry aspects of Canada's foreign policy, forestry and rural development, proposal for the creation of a provincial Ministry of Forestry, and commentaries on provincial forestry legislation. Position papers are brought up-to-date as required by the evolution of issues and the knowledge base.

Because professionally trained foresters are essential to the administration of a modern forestry program (thus, in the public's best interest), many times in its history the Order identified the need for more professional foresters in government and industry to administer the province's forests.

In the past 12 to 18 months the Order has participated in several events that have helped it to pursue the objective of enlarging its sphere of influence. Some of these are:

- position paper presented to the Canadian Standards Association on sustainable forestry.

- position paper delivered to the Summit on Rural Life (importance of enhancing and developing the province's forest resources; the need to increase forest access as a way to stabilize communities).

- contributed to the publication The Forest of the Inhabited Region of Quebec, a movement to democratize the management of Crown forests in Quebec through partnerships formed among all stakeholders: industry, provincial government, municipalities, and others.
- participant at the Private Forestry Summit, where it defended such principles as: the role of the forest in the socioeconomic development of the regions; recognizing the priority of properly managing private forests; the need to pass umbrella legislation to consolidate these principles.

- one of the architects of the Summit on Quebec Landscapes. This meeting adopted a common interprofessional declaration that recognized the importance of landscapes in professional practice.

Other communications projects that have helped to increase the Order's public presence:

- participated in the FAO congress in Quebec City.

- helped finance the House of the Tree in the Montreal Botanical Gardens. (Donated approximately $\$ 20,000$ to help with the establishment of a building devoted to the trees and forests of Quebec, highlighting the multiple uses of trees and the people who work to enhance trees and forests).

- released for the membership a 20-page working paper on clearcutting, and a 27-page survey of members' salaries. The latter describes members' salaries in terms of their experience, qualifications, and type of work, and provides a tool that can be used for promotions and for salary negotiations.

- creation of a kiosk to help represent the Order at professional and public events throughout the province (see budget items above).

L'Aubelle. The Order's news bulletin was initiated in 1946 as La Chronique, and was renamed in 1973. Since then it has evolved into a 28-page, high-quality professional bulletin that is published six times per year in a glossy magazine format, 28 pages with a press run of 2600 copies. More than $20 \%$ of the cost of its publication is covered by ads (see budget items above).

Logo. An organization's public image is reflected in the symbol it uses to represent itself. A coat of arms was adopted by the Order in 1948, but by the 1970s it no longer suited the times. The result was a new defining symbol - a visually effective logo that was adopted in 1981 (Fig. 3).

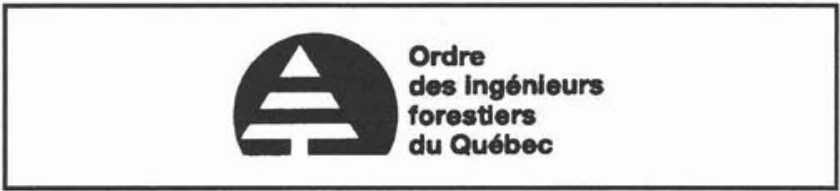

Fig. 3. Logo of the OIFQ (red on white background).

\section{The Future}

Strategic Plan. As Côté (1996) reports, in 1993 the Administrative Council felt that the Order needed to reorient itself in light of the profound changes being experienced in Quebec forestry. To address this, a 5-year strategic plan was implemented for the period 1994-1998, which included redefining the Order's mission and identifying four main strategies:

- improve the quality of professional services provided by foresters and their Order.

\footnotetext{
${ }^{8}$ Within a few years of deposing this position paper with the government, Quebec brought in a land use policy to protect arable lands from unwarranted development, something that provinces such as Ontario have yet to do - with the result that thousands of hectares of productive lands continue to be lost each year.
} 
- increase foresters' expertise.

- increase the leadership role of the Order and enlarge its radius of influence on forestry issues in Quebec.

- improve the management of the Order's activities.

These strategic objectives are now being acted upon by:

- ensuring that members keep up to date on forestry-related legislation and regulations.

- emphasizing to members the need to avail themselves of continuing education opportunities, and by increasing the emphasis on members' demonstrating their commitment to continuing education when inspected. A representative of the Order sits on each of the three committees at Laval University's Faculty of Forestry and Geomatics, thus ensuring that the Order influences the curriculum content.

- increasing the Order's presence in public debates on forestry issues, taking part in more forestry-related activities, and ensuring an increased visibility (e.g., position paper on the current consultations with the Quebec government regarding the inhabited forest policy; production of a summary of the working document on clear-cutting for the general public and the media; promotion of the Manuel de foresterie and of the professionalism of foresters; pamphlet for use by schools and the public to promote forestry as a profession).

- combining the positions of President and Executive Director.

\section{Conclusions}

The OIFQ was founded by an exceptional group of foresters, likely comparable to such pioneers of American forestry as Gifford Pinchot (Clepper 1971). They established an avant-garde vision for the Order's role in society, and it is that vision that remains the guiding force to this day.

The values identified by the Order today are:

- openness and accessibility

- objectivity

- credibility

- integrity

- commitment to forestry, and to social and environmental issues.

By working relentlessly over a period of many decades to see Quebec society fully accept foresters as professionals, the OIFQ has gained the respect of successive provincial governments, non-governmental organizations, and the general public. For example, the Ministry of Natural Resources often requests the Order for its opinions on issues before drafting legislation (M. Côté, pers. comm.). A notable example of this was the redrafting of the Forestry Law of Quebec in 1986, when the Order's draft legislation was largely written into the law.

Certain features of Quebec forestry have likely helped to strengthen the OIFQ organization. The vast majority of foresters in the province graduated from Laval University, so by joining the Order they can continue to enjoy the esprit de corps of an alumni. Also, virtually all graduating foresters from Laval University have French as their mother tongue, so most tend to stay in the province. However, these are secondary reasons for the energy behind the Order, which primarily has come from its desire and drive to be the voice of Quebec forestry, in the same sense that medical doctors speak on behalf of issues relating to traditional medical practice.
Based on the history of the OIFQ, certain deductions can be drawn related to professional foresters' associations and their role in society:

Licensing not a panacea. Foresters in jurisdictions outside Quebec may be tempted to think that licensing per se will bring about a renaissance of their association by creating a stronger membership base and better financing, thus allowing it to play a larger role. As the example of the OIFQ shows, however, neither licensing, nor the size of the membership and budget has been the guiding force behind their success. Rather the keys have been their Code of Ethics, which obliges them to be a neutral spokesperson for the people of Quebec in forestry matters, and their commitment to advocacy. Indeed, the membership base remained below 700 members until about 1970, when membership dues were only $\$ 70$, yet because of the commitment to advocacy the work accomplished up to that time was truly herculean.

Licensing versus advocacy. In the debate about the licensing of foresters and the role of advocacy, one view may be that the two are mutually exclusive, that being licensed would cause an association to restrict its public role. This view may be held from a misplaced fear that advocacy by foresters on behalf of good forestry practices may somehow be showing 'self-interest'. Such an interpretation of licensing does not address its main purpose - of foresters protecting the public good by protecting the forest resource. It is arguable that such an interpretation would result in an association virtually muzzling itself within society, so that the forestry experts, those best suited to advise the public, would lack a united voice to address vital forestry issues. Rather than helping the public interest, such a inward-looking professional group would harm by omission the best interests of the public, the reasons which were stated by the president of the OIFQ in 1938, as quoted above.

Freedom of expression. In matters of forest policy it is inevitable that factions exist. In Quebec, the OIFQ plays a neutral role by bringing together in its Council a group of foresters from a variety of backgrounds. Thus, positions taken by Council are seen by the public as coming from the Order-as positions of the organization, not of individuals. The OIFQ Council, being made up of 17 members, provides for a broader base of viewpoints than would a smaller group.

Because the members elected as OIFQ administrators represent the range of employers, an individual is obliged to vote on behalf of all, not to represent his or her employer's natural bias. Also, the Order's Code of Ethics obliges members to use their expert knowledge to base professional opinions on what is best for the resource, not for themselves, for policies being promulgated by their employer, for the benefit of the Order, or the status quo.

Professional forestry associations as an extension of science. Professional associations are a reservoir of knowledge and expertise in a given field. For this reason it can be argued that professional foresters' associations have an ethical duty to make society aware of important forestry issues and how best to address them. Foresters have been trained in forestry science, therefore their professional association can be seen as an arm of science- 
a grouping of individuals who have received advanced training, and who are serving society by applying their knowledge and expertise. In this light, advocacy should be embraced by registered professional foresters' associations so that they can fulfil their mandate to society. A policy on advocacy is thus independant of whether an association is licensed.

Foresters as communicators. How often do we hear messages to the effect that, "foresters aren't communicators - they don't know how to get their view across to the pubic, so bad legislation results from an uninformed public pressuring their elected representatives," or "foresters have no constituency." Refreshingly, at least one group of foresters in Canada have never subscribed to these notions and have accomplished much as a result. With the need greater than ever for a well-informed public and elected representatives, professional foresters' associations across the country can and should play a key role in communicating sound forestry policies based on good science. A failure to do so will result in their marginalization. As the proverb says "nature abhors a vacuum". Should professional foresters' associations be unwilling to take part in the forest policy dialogue, then it is certain that other groups will continue to fill the void created by foresters conspicuous by their absence.

Because of its mandate for advocacy, a strong communications plan to put it into effect, and the strength accorded it by licens- ing, the Ordre des ingénieurs forestiers du Québec has rendered yeoman service to the people of Quebec, and is well positioned to shape the continuing evolution of the practice of forestry. The forests and the public in all provinces and territories could benefit if professional foresters' associations were formed and equipped with similar tools.

\section{Acknowledgements}

The author wishes to thank Suzanne Bareil, ing.f. and Pierre Breton, ing.f., Secretary of the Order and Communications Director, respectively, and Marc Côté, ing.f., for their help in providing background information for this article. He also thanks the reviewers, especially Dr Roy Sutton, Emeritus Scientist with the Canadian Forest Service, for his editorial suggestions.

\section{References}

Clepper, H. 1971. Professional forestry in the United States. John Hopkins Press, Baltimore, MD. 337 p.

Côté, M. 1996. Portrait historique d'une profession. Ordre des Ingénieurs forestiers du Québec, Sainte-Foy, QC. 36 p.

Krystofiak, D. 1996. Canadian Federation of Professional Foresters Associations - Registered Professional Forester's proper use of title. For. Chron. 72: 653-656.

Ordre des Ingénieurs forestiers du Québec. 1996. Rapport annuel 1995-1996. Sainte-Foy, QC. 27 p. 